\title{
Economic policy uncertainty and housing returns in Germany: Evidence from a bootstrap rolling window $^{* 1}$
}

\author{
David $\mathrm{Su}^{2}$, Xin $\mathrm{Li}^{3}$, Oana-Ramona Lobonț ${ }^{4}$, Yanping Zhao ${ }^{5}$
}

\begin{abstract}
The purpose of this investigation is to research the causal link between economic policy uncertainty (EPU) and the housing returns (HR) in Germany. In the estimated vector autoregressive models, we test its stability and find the short-run relationship between HR and EPU is unstable. As a result, a time-varying approach (bootstrap rolling window causality test) is utilized to revisit the dynamic causal link, and we find EPU has no impact on HR due to the stability of the real estate market in Germany. $H R$ does not have significant effects on EPU in most time periods. However, significant feedback in several sub-periods (both positive and negative) are found from HR to $E P U$, which indicates the causal link from HR to EPU varies over time. The empirical results do not support the general equilibrium model of government policy choices that indicate EPU does not play a role in the real estate market. The basic conclusion is that the real estate market shows its stability due to the social welfare nature and the rational institutional arrangement of the real estate in Germany, and the real estate market also shows its importance that it has significant effect on the economic policy choice in some periods when negative external shocks occur.
\end{abstract}

Key words: housing returns, Economic Policy Uncertainty, time-varying causality

JEL classification: C32, G12, G18

* Received: 04-02-2016; accepted: 17-06-2016

1 This work is supported by the National Social Science Foundation (No. 15BJY155), and Supported by a grant from Iceland, Liechtenstein and Norway through the project 14-SEE-PCRO-TIMISOA01 KnowReset, Contract no. 2/21/07.2014.

${ }^{2}$ Full Professor, Department of Finance, Ocean University of China, Shandong 266100, China. Scientific affiliation: international finance. Phone: +8618661491158. E-mail: 2303639470@ qq.com (corresponding author).

3 Master, Department of Finance, Ocean University of China, Shandong 266100, China. Scientific affiliation: mathematical finance methods and applications. E-mail: 912393320@qq.com.

4 Associate Professor, Department of Finance, West University of Timisoara, Timisoara, Romania. Scientific affiliation: public finance.E-mail: lobont_oana@yahoo.com.

5 Associate Professor, Department of International Trade, Ocean University of China, Shandong 266100, China. Scientific affiliation: international trade and environment. E-mail: qupipizyp@163.com. 


\section{Introduction}

This paper investigates if causal relationship exists between economic policy uncertainty (EPU) and the real estate market. The reason we research on this topic is that the impact of EPU on real estate fluctuations has attracted widespread attention by the public, especially after the subprime crisis. It is natural to associate volatile house prices with an increase in uncertainty because policymakers are likely to respond to house price shocks. As the real estate market plays an important role in an economy, and the uncertainty of economic policy could affect investors' decision on the real estate, these intrigued us to test if the causal relationship exist, and how does it varying over time. The relationship between the real estate and economic policy is an important issue since both of them are crucial to a countries macroeconomic and social welfare. With considering structural changes, the purpose of this study has profound policy implications because it is helpful for the government to identify policy effectiveness to the real estate under different macro backgrounds.

Why we choose to test this relationship in Germany? In contrast to several countries where the real housing price is increasing, in Germany, it decreased at an average rate of approximately 1\% per year from 1997 to 2014. Although the housing price tends to rise in U.S., U.K. and Japan, it remains stable in Germany due to the sound market mechanism and credit system, as well as a rational longterm policy orientation (Voigtländer; 2009, 2014). The impact of the real estate market on economy is much more concerned after the outbreak of the subprime mortgage crisis (Demyanyk and Van Hemert, 2011). The global financial crisis has a rather adverse impact on the economy of major advanced countries, and Germany experienced the most serious economic recession since 1949. However, Germany's economy recovered relatively quickly. In general, EPU in Germany is relatively stable, while other countries show a clear upward trend and remain at a high level after the global financial crisis. Specifically, German economy maintained stability during the raging European sovereign debt crisis and the bleak economic prospects. The stabilization in the real estate market has played a significant role in Germany's economic recovery (Voigtländer, 2014).

Causal relationship between two series could be inaccurate due to structural changes in the full-sample (Balcilar and Ozdemir, 2013). As a result, the bootstrap sub-sample rolling window causality test is utilized to revisit the link between EPU and housing returns (HR). The sub-sample approach can identify the time-varying causal link. The results from the rolling window approach reflect a more accurate causality than the full-sample causality test. This paper aims to test the causality between EPU and HR under the framework of the general equilibrium model of government policy choices (Pastor and Veronesi, 2013), and tests if EPU plays a role in the real estate in Germany. 
For the research of the stated problems, the following hypothesis has been set: uncertainty of the economic policy has effect on the real estate market, and volatility in the real estate market also affects government's policy choices, thereby increasing uncertainty of economic policy.

This issue is structured as follows. Section 2 is the literature review. Section 3 explains the theoretical model and introduces the methodology. Section 4 describes the corresponding data and provides the empirical results. Section 5 gives the interpretation of empirical results and their policy implications. Section 6 concludes the study.

\section{Literature review}

It has undergone a process of evolution that how EPU affects the investment decision in the real estate market. Calcagnini and Saltari (2000) argue that uncertainty can reduce demand for capital, their results indicate the importance of uncertainty effects on the investment. Baker et al. (2013) prove that policy concerns account for an unusually high share of overall economic uncertainty, and their results prove the importance of uncertainty regarding policy changes. Pastor and Veronesi (2012) propose a theoretical model to describe the uncertainty of government policy choices and argue that political uncertainty increases the equity premium, which may result in higher costs of financing real estate projects. They systematically demonstrate the impact of EPU on the investment with the improved theoretical model. Policy uncertainty can impact the various sectors of the economy; the world economy has undergone huge fluctuations and has yet to emerge from the post-crisis era. Aizenman and Marion (1993) find that policy uncertainty can suppress the investment. Brogaard and Detzel (2015) find that EPU earns a significant negative risk premium in the portfolios and argue that EPU is an important risk factor for equities.

As for methodology, empirical studies have, for the most part, employed the fullsample test to investigate the causal link between the real estate market and policy uncertainty. Aoki et al. (2004) argue that the credit market may have structural changes, and this characteristic can the effectiveness of monetary policy on the real estate market. Aye et al. (2014) show that a deficit spending shock has no impact on housing prices. A deficit-financed tax cut shock persistently increases housing prices, while a balanced budget shock permanently decreases housing prices. However, the monetary policy and deficit spending shock cannot reflect all effects from EPU to the real estate market. Sum and Brown (2012) examine the effect of EPU on the performance of the real estate sector and find no significant causal link from EPU to the real estate sector. Ajmi et al. (2014) discover a two-way transmission channel between Real Estate Investment Trusts (REIT) conditional 
volatility and macroeconomic uncertainty and find no significant link between them. However, their results may be inaccurate due to the structural changes caused by huge economic fluctuations. Structural changes may cause the results to be unreliable, and the results from them cannot show the positive or negative impacts specifically.

Previous studies mostly test the link between real estate and the monetary policy in Germany; however, monetary policy cannot completely contain the policy changes. Calza et al. (2013) investigate the transmission mechanism between housing finance and monetary policy in Germany, and they find that residential investment and house prices are usually more responsive to policy shocks when the mortgage market is flexible; dynamic links between policy shocks and house prices can be tested with the method of a two-sector dynamic stochastic general equilibrium model (DSGE model). These studies mostly focus on the real estate in Germany from the perspective of monetary policy and the housing finance. Furthermore, without considering the structural changes, their result may not be accurate (Balcilar and Ozdemir, 2013) due to the impact of exogenous economic variables such as the financial crisis. Furthermore, these studies cannot identify whether the impact of policy uncertainty is positive or negative. Significantly different from previous studies, we utilize the time-varying bootstrap sub-sample causality test to test the causal link between EPU and HR in Germany. To the best of our knowledge, this is the first study to test for relationship between EPU and the real estate market in Germany with this method.

\section{Methodology}

\subsection{Theoretical model}

We use the model from Pastor and Veronesi $(2012,2013)$ to explain the mechanism between EPU and HR. First, suppose a real estate market where the investors (indicated by $m$ ) are continuous with $m \in[0,1]$ in the limited time interval of $[0, T]$. The capital of investor $m$ at time $t$ is represented by $B_{t}^{m}$. All investors' capital is equivalent at the beginning $\left(B_{0}^{m}=1\right)$. Investor $m$ invests in a linear way where the profit of return $\left(H R_{t}^{m}\right)$ is random. All profits from investing in real estate will be reinvested. In this case, the capital of investor $m$ changes as $d B_{t}^{m}=B_{t}^{m} d H R_{t}^{m}$. The following regression equation can be constructed in the time interval of $t \in[0, T]$ :

$$
d H R_{t}^{m}=\left(\mu_{1}+g_{t}\right) d t+\sigma d Z_{t}+\sigma_{1} d Z_{t}^{m}
$$

where $\left(\mu_{1}, \sigma, \sigma_{1}\right)$ are constants and can be observed. Among them, $\mu_{1}$ denotes the other factors that affect HR, $\sigma$ and $\sigma_{1}$ are the coefficient. $Z_{t}$ is a Brownian motion of the system, and $Z_{t}^{m}$ is an independent Brownian motion of investor $m$. The constant $\mu_{1}$ denotes other factors affecting $d H R_{t}^{m}$. The variable $g_{t}$ denotes the average 
coefficient of variation of economic policy gains for investors' profitability. The economic policy has no relationship with profitability if $g_{t}=0$.

The economic policy's impact $g_{t}$ will stay constant until the policy is changed at a given time $\tau(0<\tau>T)$. At time $\tau$, the government chooses to change the policy or not. The value of $g_{t}$ can be described as follows:

$$
g_{t}= \begin{cases}g^{0} & \text { for } t \leq \tau \\ g^{0} & \text { for } t>\tau \text { if the old policy is retained } \\ g^{n} & \text { for } t>\tau \text { if the new policy } \mathrm{n} \text { is chosen, } n \in\{1, \ldots, N\}\end{cases}
$$

In Equation (2), the impact of the old policy is represented by $g^{0}$. The $n$-th new policy is represented by $g^{n}(n=\{1, \ldots, N\})$. The average profitability changes if a policy changes from $g^{0}$ to $g^{n}$. All policies are effective immediately; however, the value of each policy is unknown in the time interval of $[0, T]$. That is, the economic policy that impacts investor profitability is uncertain. Policy uncertainty can be denoted as the variance of $g_{t}\left(E P U=\sigma_{g}\right)$.

The investors' utility depends on their wealth and risk attitude. In the initial moments $(T=0), H R$ of all investors is equivalent and can be obtained at time $T$. Suppose all the returns are reinvest. It should be assumed that the information is complete; thus, each investor exactly knows the current policy. The government is also maximizing its utility. However, different from the investors, the policymaker also faces a "political cost" when the old policy is changed. $C^{n}>1$ indicates that the political cost is higher than the benefit, and $C^{n}<1$ indicates that the political benefit is higher than the cost. Only the government can observe the value of $C$ and decide policy according to $C$. Since $E(C)=1$, the government is expected to maximize the investor's utility, but it may deviate from this objective randomly for the political cost is uncertainty. The investors cannot observe $C$; they only know its distribution. Political uncertainty can be represented by the variance of political cost $\left(\sigma_{c}\right)$. This uncertainty is complex, and it is hard for investors and policy-makers to predict the outcome of a political decision. Political uncertainty causes an uncertainty into policy changes $\left(E P U=\sigma_{g}\right)$, and causes reactions of $H R$ at time $\tau$.

We investigate the relationship between EPU and HR in Germany by applying a Granger casualty test under the framework of the bivariate VAR presented by Balcilar et al. (2010). We firstly test the causality with using the bootstrap fullsample test. Then, we utilize the parameter stability test to verify the existence of structural changes. Finally, we revisit the causal link with using the bootstrap sub-sample causality test. The principle of bootstrap full-sample causality test, parameter stability test and the sub-sample rolling window test are as follows. 


\subsection{Bootstrap full-sample causality test}

According to Sims et al. (1990), statistics such as the Likelihood Ratio (LR) and Lagrange Multiplier (LM) may not have standard asymptotic distributions because structural changes always exist in time series and the VAR model (Sims et al., 1990; Toda and Phillips, 1993, 1994). In such a scenario, Toda and Yamamoto (1995) proposed a modified Wald test, which acquires standard asymptotic distribution for the Wald test by estimating an augmented VAR model with I(1) variables. However, it fails in small and medium samples according to Monte Carlo simulations. Shukur and Mantolos (2000) considered the critical values of the residual-based bootstrap method (the RB method). Moreover, several studies have confirmed its effectiveness without considering whether the two variables are not co-integrated (Mantalos and Shukur, 1998; Shukur and Mantalos, 2000; Mantalos, 2000; Balcilar et al., 2010). Shukur and Mantalos (2000) proved the RB method is especially excellent for standard asymptotic tests and for power and size properties in small sample corrected LR tests. Thus, we used the RB based on modified-LR statistics.

We considered the VAR process as follows:

$$
y_{t}=\phi_{0}+\phi_{1} y_{t-1}+\ldots+\phi_{p} y_{t-p}+\varepsilon_{t}, \quad t=1,2, \ldots, T
$$

where $\varepsilon_{t}=\left(\varepsilon_{1}, \varepsilon_{2 t}\right)^{\prime}$ follows a zero mean, independent, white noise process with nonsingular covariance matrix, and optimal lag length $p$ can be obtained from the Schwarz Information Criteria (SIC). By splitting $y_{t}$ into two sub-vectors, $y_{t}=\left(y_{E P U, t}, y_{H R, t}\right)^{\prime}$; thus, the above equation can be written as the following:

$$
\left[\begin{array}{c}
y_{E P U, t} \\
y_{H R, t}
\end{array}\right]=\left[\begin{array}{c}
\phi_{10} \\
\phi_{20}
\end{array}\right]+\left[\begin{array}{ll}
\phi_{E P U, E P U}(L) & \phi_{E P U, H R}(L) \\
\phi_{H R, E P U}(L) & \phi_{H R, H R}(L)
\end{array}\right]\left[\begin{array}{c}
y_{E P U, t} \\
y_{H R, t}
\end{array}\right]+\left[\begin{array}{c}
\varepsilon_{E P U, t} \\
\varepsilon_{H R, t}
\end{array}\right]
$$

where $y_{E P U, t}$ is EPU, and $y_{H R, t}$ is HR. $\phi_{i j}(L)=\Sigma_{\mathrm{k}=1}^{\mathrm{p}+1} \phi_{i j, k} L^{k}, L$ is the lag operator $\left(L^{k} x_{t}=x_{t-k}\right)$.

We tested the null hypothesis that HR does not Granger cause EPU by imposing the restriction where $\phi_{12, k}=0, k=1,2,3, \ldots, s$. The null hypothesis that EPU does not Granger cause HR can be tested in the same way. Thus, if the null hypothesis is rejected, then HR Granger cause EPU significantly.

\subsection{Parameter stability test}

One of the assumptions for the full-sample test in VAR model is that the parameters are constant. This assumption may be wrong if structural changes are shown in the underlying full-sample time series; that is, the full-sample results become null and the causal links become unstable (Balcilar and Ozdemir, 2013). Thus, we tested the stability of parameters both in the short-run and in the long-run. We examined 
the stability of the short-term parameters by using the Sup-F, Mean-F and Exp-F tests (Andrews 1993; Andrews and Ploberger 1994). These tests can be utilized to investigate short-run parameter stability. We also use the $\mathrm{L}_{\mathrm{c}}$ test from Nyblom (1989) and Hansen (1992) to investigate if parameters are stable in the long-run. These tests were calculated from the sequence of LR statistics, which examine the stability of parameters against the alternative of a single structural break at an unknown point. Andrews (1993) points that, statistics require 15 percent trimming from both ends of the sample to test the stability of parameters in the short-run. As a result, the fraction of the sample in $(0.15,0.85)$ was needed.

\subsection{Sub-sample rolling-window estimation}

Based on the above analysis, it is necessary to use the rolling-window bootstrap method (Balcilar et al., 2010). There are two advantages of using the rolling method. First, a rolling window is applicable when the causal link between variables is time-varying. Second, since structural changes exist, a rolling method is instable in different sub-samples.

The rolling window techniques rely on fixed-size sub-samples sequentially rolling from the beginning to the end of the full sample (Balcilar et al., 2010). In this premise, suppose the rolling window including $m$ observations, then we can obtain $T-m$ sub-samples, that is, $\tau-m+1, \tau-m, \ldots, T$ for $\tau=m, m+1, \ldots, T$. Every sub-sample can be estimated, and the RB-based modified-LR test can ensure the accuracy of the results. The time-varying causality between HR and EPU can be intuitively observed by calculating the bootstrap p-values of these estimation. We utilize the bootstrap method to obtain a large number of estimation, and the average of them $\left(N_{b}^{-1} \Sigma_{21, k}^{p} \hat{\phi}_{21, k}^{*}, N_{b}^{-1} \Sigma_{12, k}^{p} \hat{\phi}_{12, k}^{*}\right)$ are defined as the impact of EPU and HR, where EPU and HR are an explained variable, respective, and $N_{b}^{-1}$ is the repetitions with using the bootstrap. Both $\hat{\phi}_{21, k}^{*}$ and $\hat{\phi}_{12, k}^{*}$ are bootstrap estimates from the VAR models in Equation (4). In the confidence interval of $90 \%$, the lower and upper limits equal the $5^{\text {th }}$ and $95^{\text {th }}$ quantiles of each of the $\hat{\phi}_{21, k}^{*}$ and $\hat{\phi}_{12, k}^{*}$, respectively (Balcilar et al., 2010).

There are two conflicting objectives in the rolling-window estimation. The first is the accuracy of the model estimates, the second is the representativeness of the method over the sub-sample period. The window size affects the precision of estimations, and influences the number of observations. A large window with more observations can improve the accuracy but it also reduces the representativeness in the presence of heterogeneity. However, a small window size may improve the representativeness and reduce accuracy. Consequently, we must select a suitable size of the window to ensure the representativeness and the accuracy. Pesaran and Timmerman (2005) demonstrate that the optimal window size relies on the persistence and size of the break by assessing the window size under structural 
change, which is according to square root mean square error. More importantly, based on Monte Carlo simulations, they propose that the minimum limit of window size is 20 when there are frequent breaks. Taking this and the two conflicting demands of the previous paragraph together, we choose the size of 24 months. A large window size is needed to ensure the accuracy of parameter estimates, but a window size that is too large may increase the risk of including some of these multiple shifts in the window sample claims for a smaller window size. The bootstrap method can effectively increase the accuracy increasing the number of repetitions when the window size is small.

\section{Empirical data and analysis}

\subsection{Data sources}

We use the monthly data covering the period from 1997:M1 to 2014:M8. In this time period, the German economy experienced a series of fluctuations. The Deutscher Aktien index (DAX) in Germany had declined 1.3\% in 1998 during the Russian financial crisis, and the gross domestic product (GDP) was noticeably declining, showing a year-on-year growth of $-1.7 \%$ in the fourth quarter of 2008 after the subprime crisis happened in 2007, for instance. According to Baker et al. (2013), the EPU index ${ }^{6}$ includes uncertainties regarding tax, spending, monetary and regulatory policy by the government that is calculated from 3 components: the frequency that economic policies appears in the newspaper, the number of expired code, and the extent of forecaster disagreement over future inflation and government purchases. According to Pastor and Veronesi (2012), the government is expected to maximize the investor's utility, but it may deviate from this objective randomly for the political cost is uncertainty, and this uncertainty causes the policy change is uncertainty (EPU). It also makes the market more volatile, especially in the period of economic downturn, and then, leads to changes in housing returns. In this study, both EPU and the housing price index in Germany are transformed by taking natural logarithms to correct for potential heteroskedasticity. The data of HR are obtained by taking first differences and multiplying the housing price index by $100^{7}$. Although the nominal housing price in Germany is increasingly consistently, the real housing price ${ }^{8}$ has a tendency to decrease, which is different from most developed countries whose real house prices show an upward trend. However, an intensive fluctuation emerged in 2008:M5, and from 2008:M5 to 2010:M5, real

\footnotetext{
6 The economic policy uncertainty index of Germany is taken from the Policy Uncertainty Database.

7 The housing price index is taken from the Economagic Time Series Database.

8 The real house price index (RHP) is obtained from the nominal house (NHP) price by excluding the impact of consumer prices $(\mathrm{CPI}) . R H P=N H P / C P I$. Among them, the CPI in Germany can be obtained from the International Monetary Fund (IMF) electronic database.
} 
house prices in Germany showed an increase of $1.32 \%$, which reflects structural changes in the real estate market in Germany due to the sub-prime crisis. Overall, fluctuations of the real estate market in Germany are roughly synchronized with the country's macroeconomic volatility, showing the German real estate market's relative stability. Voigtländer (2014) investigates the stability of the real estate in Germany and proves its uniqueness in retaining flat price levels over the whole period and failing to respond to any of the macroeconomic shocks. He argues that the real estate finance and the sophisticated rental market are main reasons for this stability. The EPU in Germany shows relatively huge fluctuations in contrast to the real house price index. Especially in 2012, around the time of the European sovereign debt crisis, the EPU in Germany showed the most intense volatility.

\subsection{Unit root test and full-sample causality test}

We use Augmented Dickey-Fuller test (ADF test, Dickey and Fuller, 1981) and Phillips-Perron test (PP test, Phillips and Perron, 1988) to test the stability of HR and EPU. Both the ADF test and the PP test reject the null hypothesis of nonstationarity for HR and EPU of Germany in levels. As HR and EPU are I(0), we test the full-sample causal link between HR and EPU. The optimal lag length based on Schwarz Information Criterion (SIC) of HR and EPU is 2. Table 1 shows the full-sample causality results using the RB based modified-LR causality tests. The p-values show that EPU does not Granger cause HR since the null hypothesis cannot be rejected, and the null hypothesis that HR does not Granger cause EPU can be rejected at $10 \%$ significance. These results indicate a one-way causal relationship from HR to EPU.

Table 1: Full-sample Granger causality tests in Germany

\begin{tabular}{|l|c|c|c|c|}
\hline \multirow{2}{*}{ Tests } & \multicolumn{2}{|c|}{$\mathrm{H}_{0}$ : EPU does not Granger cause } & \multicolumn{2}{c|}{$\mathrm{H}_{0}$ : HR does not Granger cause } \\
\cline { 2 - 5 } & Statistics & p-values & Statistics & p-values \\
\hline Bootstrap LR Test & 0.205 & 0.915 & $5.751^{*}$ & 0.058 \\
\hline
\end{tabular}

Notes: * denotes significance at the 10 percent level. Causality tests are based on a VAR model, with the lag-length being determined by the Schwarz Information Criteria (SIC). Residual-based bootstrap LR causality Tests, as suggested by Shukur and Mantalos (2000), are used to account for small-sample bias. The null-hypothesis is: No-causal relationship exists between the variables.

Source: Authors' calculation

The full-sample test indicates EPU does not play a role in the real estate market in Germany. The general equilibrium model shows that both positive impact (if the unanticipated shocks are responded properly) and negative impact (the political 
uncertainty is not fully diversifiable) exist from political uncertainty to the real estate market (Pastor and Veronesi, 2012). The full-sample causality test implies that the positive impact and negative impact are evenly matched. Furthermore, the full-sample causality test shows that the real estate market has an effect on EPU at the 10-percent significance level. As previously described, external shocks such as the subprime crisis and the European sovereign debt crisis, which have a great effect on the real estate market, can change the cost of the policy change (political cost) and then lead to a change in policy uncertainty.

\subsection{Parameter stability test}

The Full-sample estimation is not always reliable since it assumes parameters are constant across the whole sample period (Zeileis et al., 2005). Furthermore, the structural change of the economy ignored by the full-sample test may affect the real estate market. For the reasons above, we test the parameter stability and verify structural changes do exist in the full-sample time series. Three statistics, including the Sup-F, Mean-F and Exp-F tests, are utilized to test the short-run stability of parameters. We also use the $\mathrm{L}_{\mathrm{c}}$ test to estimate for the long-run stability of all parameters. The results of the stability of parameters are reported in Table 2 .

Table 2: Parameter stability tests in Germany

\begin{tabular}{|l|c|r|r|r|r|r|}
\hline \multirow{2}{*}{ Tests } & \multicolumn{2}{|c|}{ EPU Equation } & \multicolumn{2}{c|}{ HR Equation } & \multicolumn{2}{c|}{ VAR (2) System } \\
\cline { 2 - 7 } & Statistics & $\begin{array}{c}\text { Bootstrap } \\
\text {-value }\end{array}$ & Statistics & $\begin{array}{c}\text { Bootstrap } \\
\text { p-value }\end{array}$ & Statistics & $\begin{array}{c}\text { Bootstrap } \\
\text { p-value }\end{array}$ \\
\hline Sup-F & $23.285^{* * *}$ & 0.007 & 15.248 & 0.132 & $25.565^{*}$ & 0.076 \\
\hline Mean-F & $11.157^{* *}$ & 0.012 & 6.600 & 0.194 & 13.650 & 0.114 \\
\hline Exp-F & $8.127^{* * *}$ & 0.008 & 4.347 & 0.206 & 9.100 & 0.101 \\
\hline $\mathrm{L}_{\mathrm{b}}^{\mathrm{c}}$ & & & & & $2.637^{* *}$ & 0.036 \\
\hline
\end{tabular}

Notes: We calculate p-values using 10,000 bootstrap repetitions. ${ }^{*},{ }^{* *}$ and ${ }^{* * *}$ denote significance at 10,5 and 1 percent, respectively.

${ }^{b}$ Hansen-Nyblom $\left(\mathrm{L}_{\mathrm{c}}^{\mathrm{b}}\right)$ parameter stability test for all parameters in the VAR (2) jointly. Residual-based bootstrap LR causality Tests, as suggested by Shukur and Mantalos (2000), are used to account for small-sample bias.

Source: Authors' calculation

Although the null hypothesis of Sup-F test, Mean-F test and Exp-F test is constant, their alternative hypotheses are different (Andrew and Ploberger, 1994). Among these three statistics, the Super-F tests whether a shift in regime occurs, while the Mean-F and Exp-F test the gradual stability of the model over time and assume that the parameters follow a martingale process. The Sup-F statistic in Table 2 suggests that shifts in the EPU equation and VAR (2) system exist at the significant 
of $1 \%$ and $10 \%$, respectively. The Mean-F and Exp-F suggest that the EPU equation may evolve gradually at the significance level of 5-percent and 1-percent, respectively. However, all statistics suggest that the HR equation cannot reject the null hypothesis of parameters following a martingale process. The $\mathrm{L}_{\mathrm{c}}$ statistics test against the alternative that the parameters follow a random walk process (Granger, 1996), indicative of parameter non-constancy in the VAR (2) model. Overall, due to the instability of short-run parameters, the results of the full sample causality test are inaccurate. To take structural changes into account, we employ rolling windows estimation to test the causal link between HR and EPU. Different from the fullsample causality test, this approach is superior in testing the causal link between two variables for the reason of time-varying across different sub-samples.

\subsection{Sub-sample rolling window causality test}

In the sub-sample rolling window causality test, we use the RB based modifiedLR causality tests to check the causal relationship between HR and EPU. The null hypothesis of the tests are that EPU does not Granger cause HR and vice versa. The bootstrap p-values of LR-statistics can be estimated from the VAR models in Equation (4) by using the rolling sub-sample data including 24-month observations. In addition, the results are presented in tests of causal relationship between HR and EPU in Germany by the approach of RB based modified-LR causality tests. Figure 1 and Figure 2 show the rolling bootstrap of p-values of LR-statistics using HR and EPU as dependent variables in Germany, respectively. Figure 3 shows the magnitudes of the impact using EPU as dependent variables. In Figure 1 and Figure 2 , null hypotheses can be strongly rejected when the rolling bootstrap of p-values is less than 10 percent.

In general, the results from the sub-sample rolling window are consistent with that of the full-sample test, and it further exhibits more accurate results (structural changes) across the full-sample time period. Figure 1 shows the null hypothesis cannot be rejected, which indicates that EPU has no effect on HR in Germany. The movements in EPU have no power in explaining HR, which imply that policy changes do not have a significant effect on the performance of the real estate market. Voigtländer (2014) explains the stability of the German housing market from comprehensive aspects such as the existence of a sophisticated rental market. Due to the low leverage in the real estate financial market and the existence of a sophisticated rental market, the German real estate market has maintained longterm stability.

Because movements in EPU have low power in explaining HR in Germany, the empirical results imply that policy changes do not have an effect on the real estate market. The reasons behind stable housing prices in Germany may be due to institutional arrangements. Those demanding housing in Germany prefer to rent 
rather than purchase (Voigtländer, 2009) due to the soundness of the housing rental market. Germany's unique "contract savings" system, as well as fixed-rate mortgage mechanism for stable prices provide a guarantee of the real estate finance. Germany has established an independent assessment of the real estate price mechanism, the "guide price" system for land, housing prices, rents and so on (Voigtländer, 2014). In German law, housing prices and housing rents are strictly controlled. Property developers and landlords will face criminal liability if the house price or the rent goes beyond a reasonable price range. The "high price" is illicit when it is $20 \%$ more than the reasonable price according to German economic crimes law, and "huge profits" are criminal when the housing price is $50 \%$ more than the reasonable prices according to Germans criminal law, for example. Tax measure is also an effective instrument in curbing excess returns by real estate agencies and real estate speculators. The developed rental market in Germany also helps in stabilizing housing prices. Due to relatively strong institutional arrangements it is difficult to influence real estate prices (Vitikainen, 2014).

Figure 1: Bootstrap p-values of rolling test statistic testing the null that EPU does not Granger cause HR

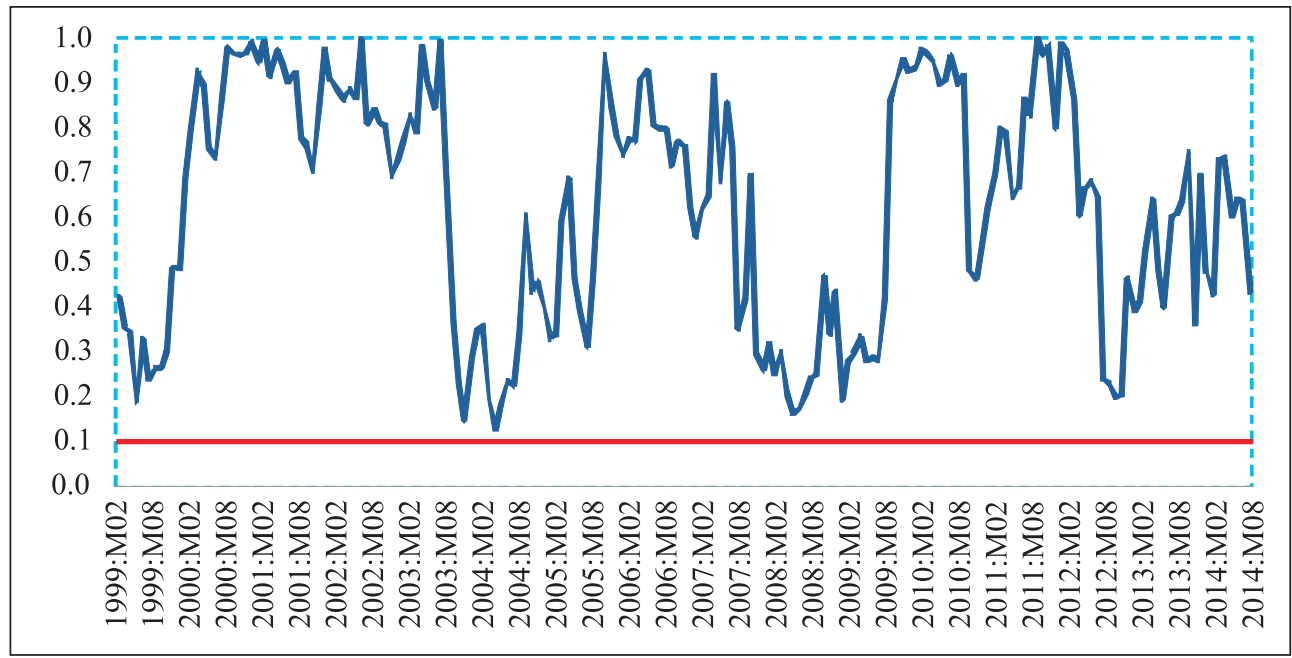

Source: Authors' calculation

In Figure 2, we find that the null hypothesis is rejected significantly in several sub-periods (1999-2000, 2001-2002, 2005-2006, 2008-2009). That is, HR has effect on EPU. The results imply the housing price guides the direction of economic policy only in some sub-periods, which indicates a time-varying nature in causal links between HR and EPU. 
David Su et al. • Economic policy uncertainty and housing returns in Germany...

Figure 2: Bootstrap p-values of rolling test statistic testing the null that HR does not Granger cause EPU

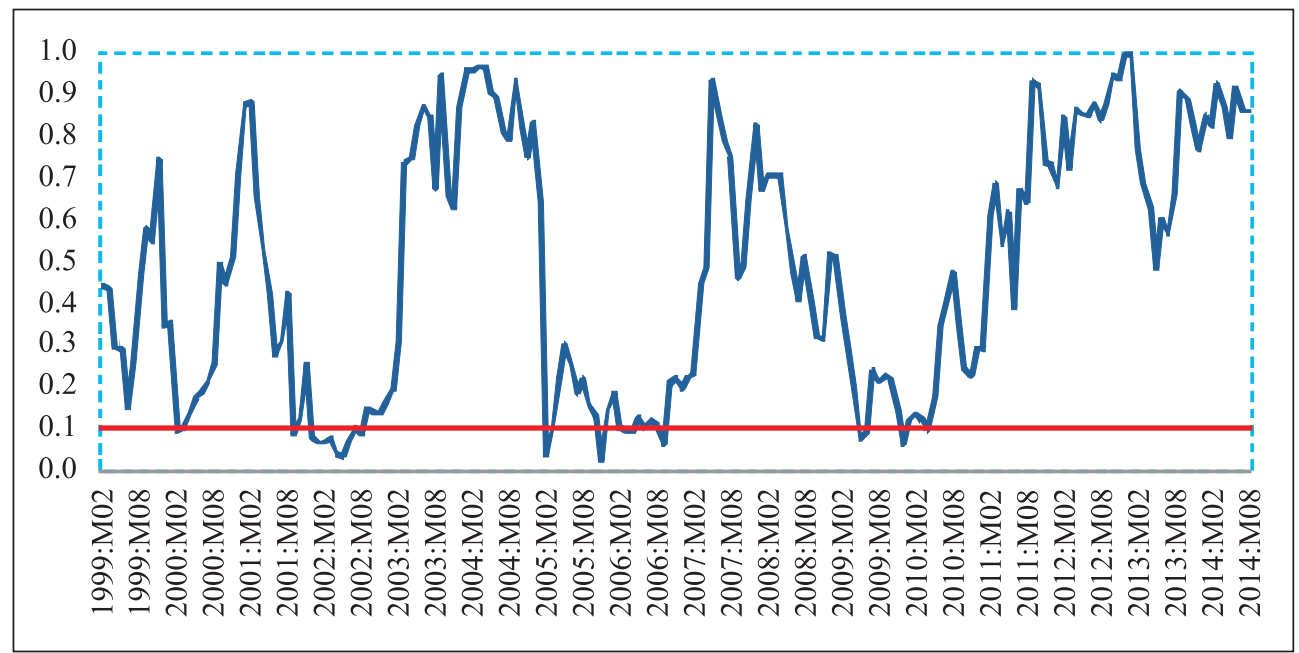

Source: Authors' calculation

Figure 3 gives the bootstrap estimates of the sum of the rolling window coefficients for the impact of HR on EPU. Both positive (2001-2002, 2005-2006) and negative effects (1999-2000, 2008-2009) exist from HR to EPU.

Figure 3: Bootstrap estimates of the sum of the rolling window coefficients for the impact of HR on EPU

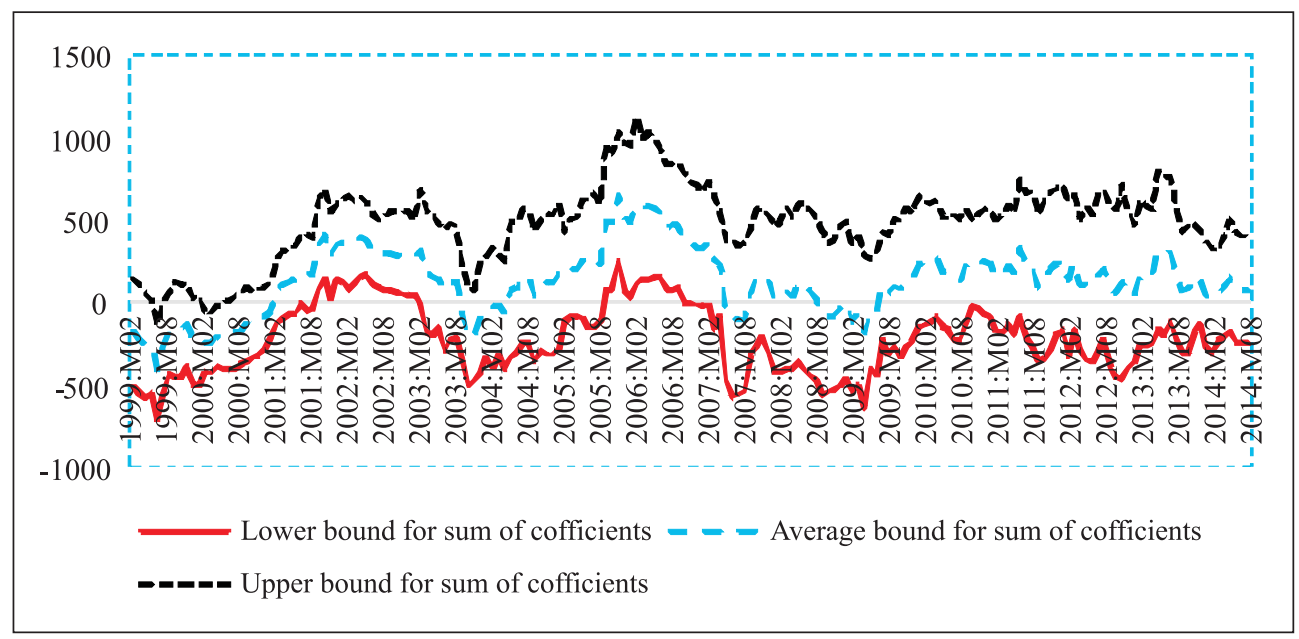

Source: Authors' calculation 
Figure 2 and Figure 3 further prove the existence of structure changes in the relationship. The result is significantly different from the full-sample causality test that it indicates the time-varying nature across the full-sample. The causality only occurs in some sub-periods indicates that changes of $H R$ cannot explain all changes of $E P U$, and verifies results from the full-sample causality test are inaccurate. We find more positive effects than negative effects exist from HR to EPU. That is, fluctuations of the real estate market exacerbate the uncertainty of economic policy in some specific periods.

\section{Results and discussion}

The results and corresponding interpretations are as follows. First, the rolling window test proves that structural changes do exist in the full-sample period. Over the past decades, Germany experienced a series of economic fluctuations, such as the Russian financial crisis, the subprime crisis and the European sovereign debt crisis that are effectively transmitted to the real economy via the real estate market. In particular, in 2008:M9, the real estate financing mortgage bank (Hypo Real Estate, HRE) in Germany was on the verge of bankruptcy because it showed a funding gap of 70 billion to 100 billion euros due to the effect of the subprime crisis, and German gross domestic product (GDP) was notably declining, showing year-on-year growth of $-1.7 \%$ in the fourth quarter of 2008 . The series of external shocks also led to structural changes in policy. The German government introduced a bailout package (the financial stability fund) and two economic stimulus plans (70 billion euros and 51.5 billion euros) to address the subprime mortgage crisis, for instance. Second, most of the windows where HR affects EPU significantly are around the Russian crisis in 1998 and the global financial crisis in 2008. That is, HR has effects on EPU only in periods of economic turmoil. Third, changes of EPU do not cause changes of HR. This result does not support results from the general equilibrium model that the high level of political uncertainty will cause a rise of the risk premium because investors need higher returns to cope with rising uncertainty (Pastor and Veronesi, 2012). Fourth, more positive effects than negative effects exist from HR to EPU. In Figure 3, we observe that both positive (2001-2002, 2005-2006) and negative effects (1999-2000, 2008-2009) exist from HR to EPU. These two time periods coincide with the Russian crisis in 1998 and the global financial crisis in 2008. German banks had huge exposure to Russia and were consequently affected by the Russian crisis that broke out in 1998. The global financial crisis that broke out in 2008 has a great shock on Germany's real economy (Karanikolos et al., 2013). Around the two financial crises, HR has a negative impact on EPU. In addition, the effects from HR to EPU during 2008 to 2009 are greater than during 1999 to 2000. Due to the impact of the financial crisis, the real estate market is sluggish, and governments took measures to cope with the decline in HR (Van der Heijden et al., 2011). The effects from HR to EPU during 
2001-2002, and 2005-2006 are positive. This reflects the fact that HR changes tend to lead to EPU changes in the same direction.

Political uncertainty does not play a role in the real estate market due to the sound market mechanism and credit system and the rational long-term policy orientation. Pastor and Veronesi (2012) argue that political uncertainty reduces the value of the government's protection to the market and makes the market more volatile when the economic is downturn based on the general equilibrium model of government policy choices. As a result, political uncertainty commands a risk premium to compensate for the risk caused by political uncertainty. However, the EPU does not lead to a higher risk premium to the real estate market in Germany, implying the positive impact (the government responds properly to unanticipated shocks) and the negative impact (political uncertainty is not fully diversifiable) are evenly matched. This result is not consistent with results of the general equilibrium model because there is an implicit assumption in the general equilibrium model that policy uncertainty is caused by the short-term policy changes while the long-term policy orientation is ignored ${ }^{9}$. Compared to other countries such as the U.K. and the U.S., the German government pays more attention to the social welfare nature of real estate, and providing housing security is one of the primary objectives of German government. As a result, the long-term policy orientation and established institutional arrangements play a more important role in real estate to maintain a stable market and ensure its social-welfare nature. On the other hand, external shocks as mentioned above reduce the cost of policy change (political cost) because its impact on the real estate market violates the objective of the government (to ensure the social-welfare nature of real estate), and then, lead to the increase of policy uncertainty.

\section{Conclusions}

The presented results of this paper proved the hypothesis that volatility in the real estate market has effect on government's policy choices. However, results are failed to prove that uncertainty of the economic policy has effect on the real estate market, and thereby increasing uncertainty of economic policy. Periods that HR has an effect on EPU are mostly around the times that the regional economy has undergone a period of depression. This result proves that structural changes in the real estate market in Germany are due to powerful external shocks that cause changes in economic policies to maintain the stability of real estate. More positive effects than negative effects exist from HR to EPU, which indicates that changes in real estate reduce the cost of policy change (political cost) and then lead to an increase in policy

\footnotetext{
9 In the general equilibrium model, a new policy is implemented at a given time $\tau(0<\tau<T)$, which implicitly assumes that the policy is changing in the full-sample time period $([0, T])$, and causes the uncertainty of policies.
} 
uncertainty. Results from the rolling window test are significantly different from previous studies since we take structural changes into account. The rolling window provides a more accurate perspective in the study of the causality between economic variables. Though the hypothesis that EPU has effect on HR is failed to be proved, it can be attribute to the social welfare nature of the real estate and rational institutional arrangement in Germany, as well as the government's reasonable response measures when negative external shocks occur. This paper makes a contribution that taking into account structural changes. To avoid inaccurate results when structural changes exist in the full-sample, we utilize a sub-sample method to identify the time-varying causal link. In terms of theoretical, this paper proves a rationally institutional arrangement is helpful to reduce the impact of economic policy uncertainty on the real estate market. Due to differences of national statistical standards of economic policy uncertainty, this research has a limitation that it lacks of an international comparison. As a result, for a more comprehensive analysis, the further research can focus on the international comparison of the relationship between economic policy uncertainty and the real estate market to find out if there is a general law in the interaction of economic policy uncertainty and the real estate market. Through the bootstrap rolling window approach, the obtained results suggest that political uncertainty does not play a role in the real estate market in Germany, which offers profound implications for policymakers and investors.

\section{References}

Aizenman, J., Marion, N. P. (1993) "Policy Uncertainty, Persistence and Growth", Review of International Economics, Vol. 1, No. 2, pp. 145-163, doi: 10.1111/j.1467-9396.1993.tb00012.x.

Ajmi, A. N. et al. (2014) "How Strong are the Causal Relationships between Islamic Stock Markets and Conventional Financial Systems? Evidence from Linear and Nonlinear Tests", Journal of International Financial Markets, Vol. 28, pp. $213-$ 227, doi: 10.1016/j.intfin.2013.11.004.

Andrews, D. W. K. (1993) "Tests for Parameter Instability and Structural Change with Unknown Change Point”, Econometrica, Vol. 61, No. 4, pp. 821-856, doi: 10.2307/2951764.

Andrews, D. W. K., Ploberger, W. (1994) "Optimal Tests when a Nuisance Parameter is Present only under the Alternative", Econometrica, Vol. 62, No. 6, pp. 1383-1414, doi: 10.2307/2951753.

Aoki, K., Proudman, J., Vlieghe G. (2004) "House Prices, Consumption, and Monetary Policy: a Financial Accelerator Approach", Journal of Financial Intermediation, Vol. 13, No. 4, pp. 414-435, doi: 10.1016/j.jfi.2004.06.003.

Aye, G. C. et al. (2014) "Fiscal Policy Shocks and the Dynamics of Asset Prices: The South African Experience", Public Finance Review, Vol. 42, No. 4, pp. 511-531, doi: 10.1177/1091142113501713. 
Baker, S. R., Bloom, N., Davis, S. J. (2013) "Measuring Economic Policy Uncertainty”, National Bureau of Economic Research, pp. 57-66, doi: 10.2139/ssrn.2198490.

Balcilar, M., Ozdemir, Z. A., Arslanturk, Y. (2010) "Economic Growth and Energy Consumption Causal Nexus Viewed through a Bootstrap Rolling Window", Energy Economics, Vol. 32, No. 6, pp. 1398-1410, doi: 10.1016/j.eneco.2010.05.015.

Balcilar, M., Ozdemir, Z. A. (2013) "The Export-Output Growth Nexus in Japan: A Bootstrap Rolling Window Approach", Empirical Economics, Vol. 44, No. 2, pp. 639-660, doi: 10.1007/s00181-012-0562-8.

Brogaard, J., Detzel, A. (2015) "The Asset-Pricing Implications of Government Economic Policy Uncertainty”, Management Science, Vol. 61, No. 1, pp. 3-18, doi: 10.1287/mnsc.2014.2044.

Calcagnini, G., Saltari, E. (2000) "Real and Financial Uncertainty and Investment Decisions", Journal of Macroeconomics, Vol. 22, No. 3, pp. 491-514, doi: 10.1016/S0164-0704(00)00142-7.

Calza, A., Monacelli, T., Stracca, L. (2013) "Housing Finance and Monetary Policy", Journal of the European Economic Association, Vol. 11, pp. 101-122, doi: 10.1111/j.1542-4774.2012.01095.x.

Demyanyk, Y., Van Hemert, O. (2011) "Understanding the Subprime Mortgage Crisis", Review of Financial Studies, Vol. 24, No. 6, pp. 1848-1880, doi: 10.1093/ $\mathrm{rfs} / \mathrm{hhp033.}$

Dickey, D. A., Fuller, W. A. (1981) "Likelihood Ratio Statistics for Autoregressive Time Series with a Unit Root”, Econometrica, Vol. 49, No. 4, pp. 1057-1072, doi: $10.2307 / 1912517$.

Granger, C. W. J. (1996) "Can We Improve the Perceived Quality of Economic Forecasts?", Journal of Applied Econometrics, Vol. 11, No. 5, pp. 455-473, doi: 10.1002/(SICI)1099-1255(199609)11:5\%3C455::AID-JAE408\%3E3.3.CO;2-5.

Hansen, B. E. (1992) "Tests for Parameter Instability in Regressions with I(1) Processes", Journal of Business and Economic Statistics, Vol. 10, No. 3, pp. 321336, doi: 10.1080/07350015.1992.10509908.

Karanikolos, M. et al. (2013) "Financial Crisis, Austerity, and Health in Europe", The Lancet, Vol. 381, No. 9874, pp. 1323-1331, doi: 10.1016/S0140-6736(13)60102-6.

Mantalos, P., Shukur, G. (1998) "Size and Power of the Error Correction Model Cointegration Test: A Bootstrap Approach", Oxford Bulletin of Economics and Statistics, Vol. 60, No. 2, 249-255, doi: 10.1111/1468-0084.00097.

Mantalos, P. (2000) "A Graphical Investigation of the Size and Power of the Granger-Causality Tests in Integrated-Cointegrated VAR Systems", Studies in Non-Linear Dynamics \& Econometrics, Vol. 4, No. 1, pp. 17-33, doi: 10.2202/ 1558-3708.1053.

Nyblom, J. (1989) "Testing for the Constancy of Parameters over Time", Journal of the American Statistical Association, Vol. 84, No. 405, pp. 223-230, doi: 10.1080/01621459.1989.10478759. 
Pastor, L., Veronesi, P. (2012) "Uncertainty about Government Policy and Stock Prices", The Journal of Finance, Vol. 67, No. 4, pp. 1219-1264, doi: 10.1111/ j.1540-6261.2012.01746.x.

Pastor, L., Veronesi, P. (2013) "Political Uncertainty and Risk Premia", Journal of Financial Economics, Vol. 110, No. 3, pp. 520-545, doi: 10.1016/j. jfineco.2013.08.007.

Pesaran, M. H., Timmermann, A. (2005) "Small Sample Properties of Forecasts from Autoregressive Models under Structural Breaks", Journal of Econometrics, Vol. 129, No. 1-2, pp. 183-217, doi: 10.1016/j.jeconom.2004.09.007.

Phillips, P. C. B., Perron, P. (1988) “Testing for a Unit Root in Time Series Regression”, Biometrika, Vol. 75, No. 2, pp. 335-346, doi: 10.1093/biomet/ 75.2.335.

Sims, C. A., Stock, J. H., Watson, M. W. (1990) "Inference in Linear Time Series with Some Unit Roots", Econometrica, Vol. 58, No. 1, pp. 113-144, doi: $10.2307 / 2938337$.

Shukur, G., Mantalos, P. (2000) "A Simple Investigation of the Granger-Causality Test in Integrated-Cointegrated VAR Systems", Journal of Applied Statistics, Vol. 27, No. 8, pp. 1021-1031, doi: 10.1080/02664760050173346.

Sum, V., Brown, K. (2012) "Real Estate Sector Response to Economic Policy Uncertainty Shocks", International Research Journal of Applied Finance, Vol. 3, No. 12, pp. 1739-1747, doi: 10.2139/ssrn.2151998.

Toda, H. Y., Phillips, P. C. B. (1993) "Vector Autoregressions and Causality", Econometrica, Vol. 61, No. 6, pp. 1367-1393, doi: 10.2307/2951647.

Toda, H. Y., Phillips, P. C. B. (1994) "Vector Autoregression and Causality: A Theoretical Overview and Simulation Study", Econometric Reviews, Vol. 13, No. 2, pp. 259-285, doi: 10.1080/07474939408800286.

Toda, H. Y., Yamamoto, T. (1995) "Statistical Inference in Vector Autoregressions with Possibly Integrated Processes", Journal of Econometrics, Vol. 66, No. 1-2, pp. 225-250, doi: 10.1016/0304-4076(94)01616-8.

Van der Heijden, H., Dol, K., Oxley, M. (2011) "Western European Housing Systems and the Impact of the International Financial Crisis", Journal of Housing and the Built Environment, Vol. 26, No. 3, pp. 295-313, doi: 10.1007/ s10901-011-9230-0.

Voigtländer, M. (2009) "Why is the German Homeownership Rate So Low", Housing Studies, Vol. 24, No. 3, pp. 355-372, doi: 10.1080/02673030902875011. Voigtländer, M. (2014) "The Stability of the German Housing Market”, Journal of Housing and the Built Environment, Vol. 29, No. 4, pp. 583-594, doi: 10.1007/ s10901-013-9366-1.

Zeileis, A. et al. (2005) "Monitoring Structural Change in Dynamic Econometric Models", Journal of Applied Econometrics, Vol. 20, No. 1, pp. 99-121, doi: 10.1002/jae. 776 . 


\title{
Neizvjesnost ekonomske politike i prinos na tržištu nekretnina u Njemačkoj na primjeru bootstrap metode ${ }^{1}$
}

\author{
David $\mathrm{Su}^{2}$, Xin $\mathrm{Li}^{3}$, Oana-Ramona Lobont ${ }^{4}$, Yanping Zhao ${ }^{5}$
}

\begin{abstract}
Sažetak
Svrha ovog istraživanja je ispitati uzročno-posljedičnu vezu između neizvjesnosti ekonomske politike (NEP) i prinosa na tržištu nekretnina (PTN) u Njemačkoj. U vektorskim auto-regresijskim modelima testirana je stabilnost odnosa NEP-a $i$ PTN-a i utvrđeno je da je kratkoročni odnos između NEP-a i PTN-a nestabilan. Kao rezultat, metoda kliznog vremenskog okvira promatranja podataka (bootstrap test kauzalnosti) koristi se da bi se preispitala dinamična uzročno-posljedična veza (veza kauzalnosti) i utvrđeno je da NEP nema utjecaja na PTN zahvaljujući stabilnosti tržišta nekretnina u Njemačkoj. U većini vremenskih razdoblja, PTN nema značajan utjecaj na NEP. Međutim, značajne povratne informacije u nekoliko pod-razdoblja ( $i$ pozitivne i negativne) ukazuju na kauzalnu vezu PTN-a prema NEP-u koja varira tijekom vremena. Empirijski rezultati ne podupiru model opće ravnoteže vladine politike izbora što ukazuje na to da NEP ne utječe na tržište nekretnina. Temeljni zaključak je da tržište nekretnina pokazuje svoju stabilnost zahvaljujući socijalnoj skrbi i racionalnom institucijskom uređenju tržišta nekretnina u Njemačkoj, a isto tako i tržište nekretnina pokazuje da ima značajan utjecaj na ekonomsku politiku izbora u nekim razdobljima kod pojave negativnih vanjskih šokova.
\end{abstract}

Ključne riječi: prinosi na tržištu nekretnina, neizvjesnost ekonomske politike, klizni vremenski okvir kauzalnosti

JEL klasifikacija: C32, G12, G18

1 Ovaj rad podupire Nacionalna zaklada društvenih znanosti (br.15BJY155), te financijska potpora Islanda, Lihtenštajna i Norveške kroz projekt 14-SEE-PC-RO-TIMISOA01 KnowReset. Ugovor br. $2 / 21 / 07.2014$.

2 Redoviti profesor, Katedra za financije, Ocean University of China, Shandong 266100, Kina. Znanstveni interes: međunarodne financije. Tel.: +8618661491158. E-mail: 2303639470@ qq.com (autor za korespodenciju).

${ }^{3}$ Magistar znanosti, Katedra za financije, Ocean University of China, Shandong 266100, Kina. Znanstveni interes: matematičke financijske metode i primjene.E-mail:912393320@qq.com.

4 Izvanredna profesorica, Katedra za financije, West University of Timisoara, Temišvar, Rumunjska. Znanstveni interes: javne financije.E-mail: lobont_oana@yahoo.com.

5 Izvanredni profesor, Katedra za međunarodnu razmjenu, Ocean University of China, Shandong 266100, Kina.Znanstveni interes: međunarodna razmjena i okoliš. E-mail: qupipizyp@163.com. 